\title{
Predicting employee engagement in an age-diverse retail workforce
}

\author{
Authors: Jacquelyn Boone James, Sharon McKechnie, \\ Jennifer E. Swanberg
}

Persistent link: http://hdl.handle.net/2345/1420

This work is posted on eScholarship@BC, Boston College University Libraries.

Use of this resource is governed by the terms and conditions of the Creative Commons "Attribution-Noncommercial-No Derivative Works 3.0 United States" (http:// creativecommons.org/licenses/by-nc-nd/3.0/us/) 


\title{
Predicting Employee Engagement in an Age-diverse Retail Workforce
}

\author{
Jacquelyn Boone James \\ Boston College \\ 140 Commonwealth Ave. \\ Chestnut Hill, MA 02467 \\ jamesjc@bc.edu \\ 617-552-2860 \\ 617-552-2859 \\ Sharon McKechnie \\ Emmanuel College \\ 400 The Fenway \\ Boston, MA 02115 \\ mckecsh@emmanuel.edu \\ 617-975-9422 \\ 617-735-9708
Jennifer Swanberg Lexington, KY 40504 jswan0@uky.edu 859-296-1363 \\ University of Kentucky \\ 2365 Harrodsburg Road \\ 859-296-1089, ext. 224
}

KEY WORDS: job quality, career stage, older workers, employee engagement, social exchange theory, retail

This work was supported by the Sloan Center on Aging and Work: Workplace Flexibility at Boston College (Sloan grant \#5000719), by the Ford Foundation (\#1050-0632), and by the organization we studied (CitiSales, a pseudonym). We are grateful to the leadership of CitiSales for its willingness to support research within its organization, and to the many employees (hourly and exempt workers, district managers, and area vice presidents) who graciously shared their time and experiences with us. We are also grateful to Dale Mahoney and Caroline Macke for their skillful interviews, and to Mac Werner for data preparation and management.

NOTE: A revised version of this paper will appear in a forthcoming special issue of the Journal of Organizational Behavior. 


\begin{abstract}
The news that the early retirement trend has been reversed and current older workers plan to work past conventional retirement ages has been widely heralded. Managers have been encouraged to make adjustments to differences in job conditions that are important to older workers. We use social exchange theory and the norm of reciprocity as a framework for examining six dimensions of job quality for their impact on employee engagement among several groups of older and younger workers at different points in the cycle of their careers in a large retail setting. Employees $(\mathrm{N}=6,047)$ were surveyed as part of a large scale research project. Exploratory factor analyses identified commonalities among 27 job quality variables and four reliable factors. Regression analyses estimated the relationship between four job conditions and employee engagement. Although the relative weights of the factors differed by career stage, the same factors: (1) supervisor support and recognition; (2) schedule satisfaction; and (3) job clarity were significant predictors of employee engagement for all age groups; (4) career development was a predictor for all but the retirement-eligible employees. Findings reveal the importance of recognizing age diversity among both young and old employees. Both theoretical and practical implications are discussed.
\end{abstract}


The news that the early retirement trend has been reversed and the current generation of older workers plans to work past conventional retirement ages has been widely heralded (Burtless \& Quinn, 2002; Munnell \& Soto, 2005; Smyer \& Pitt-Catsouphes, 2007). It has also been said that these "continuing workers" may have changing ideas about what constitutes a quality job in later life (Christensen, 2006; Quinn, 2002; Sweet \& Moen, 2006). At the same time, employers in many sectors have begun to recognize the need to retain these workers to avoid "lost knowledge" (DeLong, 2004) and deal with the void that may be created by the size of the "Baby Boom" generation approaching retirement age (Hedge, Borman, \& Lammlein, 2006). Yet, too little is known about what factors constitute job quality or effective leadership needed to guide organizations through such sweeping changes. Although there is a decades-old literature on managing older workers (see, for example, Belbin, 1965; Dennis, 1988; Sterns, Sterns \& Hollis, 1996), seldom are employees over the age of 65 the focus of study. In the past, we have seen that older workers are typically higher in job satisfaction and organizational commitment (e.g., Warr, 1994). Are retirement-eligible workers different from those who are approaching retirement ages? Are they more or less engaged than younger workers? Does the organization need to employ new strategies to keep them involved and engaged? The purpose of this paper is to examine several dimensions of job quality for their impact on the level of employee engagement among a sample of workers across a wide age range in one large organizational setting.

In general, employers more and more want to know what will engage workers and keep them energized and productive on the job and committed to the organization. Employees on the other hand want to know what the organization will do for them in terms of organizational rewards and favorable job conditions. Social exchange theory suggests that workers who feel 
valued and appreciated by the organization reward the company with discretionary effort in a form of quid pro quo (Eisenberger, Huntington, Hutchison, \& Sowa, 1986; Shore \& Shore, 1995). In short, the theory supposes that discretionary effort on the part of the organization on behalf of the employee is likely to beget discretionary effort on the part of the employee (Wayne, Shore, \& Liden, 1997). Extensive research supports the idea that employee perceptions of organizational effort on their behalf predict increased loyalty and commitment as both factors are considered elements of employee engagement. Too little attention, however, has been paid to which job conditions are most important for engaging older workers of today (for an exception, see Pitt-Catsouphes \& Matz-Costa, 2008; 2009).

Why Should Employers Be Concerned about the Needs of Older Workers?

Some researchers suggest that there may not be enough younger workers to replace the large number of workers in the Baby Boom generation who are expected to retire in the next 15 years (Herman \& Gioia, 2003; Nyce \& Schieber, 2001). Others express concern about the loss of accumulated wisdom and experience that may stall businesses that are confronted with these elevated retirement rates. DeLeong (2004), for example, has shown the ways in which systems for the transfer of knowledge are woefully undeveloped. Most importantly, in a reversal of previous trends, some employers are finding older workers preferable to younger workers (Munnell, Sass, \& Soto, 2006; Pitt-Catsouphes, Smyer, Matz-Costa, \& Kane, 2007). Even Cappelli (2003), who disputes the idea that there will not be enough workers for the needs of the future, comes to the conclusion that employers of older workers need to focus on "developing competencies in recruiting and selection, performance management, retention policies, and other practices that support their ability to find and keep good workers" (p. 232).

What Job Conditions Constitute Discretionary Effort by Employers? 
Several job conditions are said to be related to employee perceptions that the organization is exerting discretionary effort, or giving more in the bargain than they are required to do. First and foremost is the importance of support and recognition by one's supervisor. The supervisor, as an agent of the organization and performance manager, plays a central part in conveying the organization's appreciation for and concern about the employee; this is especially true of policies that support work-life integration for employees (see, for example, Kelly et al., 2008).

The role of the supervisor in social exchange theory is so important as to be considered a separate construct i.e., leader-member exchange-theory (Wayne, et al., 1997). According to these authors, “.... when organizations invest in and provide recognition for employees, they may also be encouraging the development of strong social exchange relationships" (Wayne et al., p. 105). In such relationships, the employee feels obligated to do a good job, but also to perform in ways that benefit the supervisor e.g., going beyond usual performance requirements.

According to Rhoades and Eisenberger (2002), other important dimensions of the employment experience that connote the value of employees to the business include: fairness and a list of other job rewards and conditions. The first, the importance of fairness in developing clear procedures and policies and reward systems, is one indication of the organization's respect for the employee and should have an impact on the employee's perception of organizational concern for employee well-being. The importance of fairness underlies almost any relationship and is at the heart of the reciprocity norm.

Second, job autonomy is said to be indicative of discretionary effort on the part of the organization. Autonomy on the job refers to the "employees' perceived control over how they carry out their job, including scheduling, work procedures, and task variety" (Rhoades \& 
Eisenberger, 2002, p. 700). The provision of job autonomy is an indicator of the organization's trust in employees to make good judgments as to how they will carry out their job.

Finally, role stressors on the job affect the employee's perception of support on the part of the organization. Role ambiguity is one such stressor, and involves the extent to which the employee is clear about his or her responsibilities. This stressor is structural in nature, and is a result of a lack of clarity in the expectations of the employee. A recent meta-analysis found role ambiguity to have a very strong, negative effect on job performance (Gilboa, Shirom, Fried, \& Cooper, 2008); in short, unless employees have some idea of what their organization requires of them, they cannot deliver. In contrast, those employees with low role ambiguity experience higher levels of control in their jobs, and therefore perform at higher levels (Griffin, Neal, \& Parker, 2007).

Similar to the reciprocity norm, employee engagement is seen as a two-way street: organizations must arrange for working conditions that inspire commitment, loyalty, and energy from the employee; the employee then chooses how much commitment and loyalty s/he gives back (Robinson, Perryman \& Hayday, 2004; see also Pierce, Dunham, Gardner, \& Cummings, 1989). This delicate exchange may differ from one organization to the next and perhaps for different types of workers. Our concern here is with the extent to which age is a factor in the exchange, and whether the same or different job conditions engage older and younger workers.

Who is an Older Worker?

Anyone between the ages of 40 and 70 is protected from unfair labor practices by the Age Discrimination in Employment Act (ADEA) (Burchett, 2005); thus, "older worker" spans a wide range of ages, as does "younger worker," as defined by anyone under 40 . However, because there is no consensus as to who is an older worker, researchers tend to use different definitions 
(Smyer and Pitt-Catsouphes, 2007). Indeed, Sterns and Doverspike (1989) proposed 5 different approaches to defining older workers, two of which are straightforward; chronological/legal e. g, ADEA; and functional age, which involves some appraisal of workers' physical and psychological abilities to do the job. As to the other three approaches-psychosocial, organizational, life-span — Sterns and Doverspike elaborate further.

According to these authors, psychosocial definitions of older workers take into account considerations of social perceptions of the capabilities of these workers as a class of employees. There are positive and negative attitudes and stereotypes toward both older and younger workers, but, as noted above, there are legal implications for hiring practices when labeling a worker as older (Sterns et al., 1996). The organizational approach emphasizes on-the- job experience and seniority rather than age (see for example, Kacmar \& Ferris, 1989). The life-span orientation combines all of these approaches by recognizing age norms and expectations that permeate organizations (Sterns \& Miklos, 1995). This latter approach also emphasizes considerable individual differences in aging (Baltes, Reese, \& Lipsitt, 1980). Most importantly, the life-span approach assumes that behavioral change can occur at any point in the life cycle (Sterns et al., 1996). The life-span approach makes the most sense for our purposes in that it provides a lens through which to interpret differences among a wide range of age intervals and to assess differences within both older and younger workers. Our focus, however, is on older workers, which brings us back to our question.

Who is an older worker? Many researchers of aging and work consider those employees who are approaching, and at, the conventional retirement age of 65 , to be older workers. For example, Munnell et al. (2006), is one of many research teams to have considered older workers to be those employees who were 55 and older (see also Rix, 2001). Three pieces of legislation on 
behalf of older Americans (the Older Americans Act, 1965; the Job Training Partnership Act, 1982; and the Workforce Investment Act, 2000) all use 55 and older as the delimiter (cited in Hedge et al., 2006). Currently, the fastest growing segment of the workforce is 55 and older (Dohm \& Shniper, 2007). Most importantly, the idea that " 50 is the new 40 " suggests a public perception at least that the subjective experience of age is changing (Westerhof, Barrett, \& Steverink, 2003), so that people in their 40s and even early 50s do not consider themselves to be older workers. For all these reasons, we define older workers as those who are 55 and older. Today's workplace, however, includes workers of all ages from young adulthood to the retirement-eligible and beyond, all of whom are in different stages of their careers. The life-span perspective would suggest that there might be differences among these employees on the basis of different norms and expectations about work at different points in the career cycle. Early career employees, for example, in today's context are often referred to as "emerging adults" (Arnett, 2004), or part of the "youth labor force" (Lowe, 2001). No longer expecting to get on career track with the expectation of a continuous climb up the ladder of a single organization, these young workers are slower to make career commitments than were previous young workers (Harrington \& Hall, 2007). As we will see, similar challenges to norms and expectations are occurring among older workers, some of whom are approaching retirement age or are in their middle years (James \& Lachman, 1997; Lachman, 2001; Sterns \& Huyck, 2001) and some of whom continue to work past conventional retirement ages. The question of how to engage all of these workers for optimal productivity has become a matter of increasing concern to today's business leaders.

\section{Discretionary Effort and Employee Engagement}


Employee engagement is clearly a "buzz" word in business circles along with claims that it predicts many positive outcomes for organizations (Kahn, 1990; Saks, 2006; Schaufeli, Salanova, Gonzales-Roma, \& Bakker, 2002). At the same time, it has been said that more and more employees of today are "disengaged" and costing "U.S. businesses $\$ 300$ billion a year in lost productivity" (Saks, 2006, p. 600; see also Odell, 2007). It appears that understanding the drivers of employee engagement has become an important goal in many organizations today (Lockwood, 2007; Pitt-Catsouphes \& Matz-Costa, 2009).

Although the situation is changing, most of what we know about employee engagement, as it is understood in the current workplace, comes from consultants and practitioners (Chalosfsky \& Krishna, 2009; Saks, 2006). Until recently, little academic research existed on employee engagement per se, perhaps due to the "confusion between industry and academics regarding the definition of engagement - the industry side focuses on engagement as an outcome...that can be used ...for organizational improvement," which makes it a measure of a state outcome rather than a trait (Wefald \& Downey, 2009, p. 142). On the academic side, researchers have conducted studies of various engagement measures, some state- some traitoriented, primarily with student samples, more to develop the psychometric properties of the various instruments than to understand better management practices or to learn what organizations can do to better motivate employees (Wefald \& Downey, 2009).

Still, it is important to note that the study of employee engagement is rooted in a long and continuing tradition of research on work motivation based on such theories as Maslow (1954) and Havighurst, (1954) and bears some similarity to such constructs as job involvement (Newton \& Keenan, 1983; Stagner, 1985), organizational commitment (OC) (Mathieu \& Zajac, 1990; Mowday, Steers, \& Porter, 1979); and organization-based self-esteem (OBSE), (Pierce et 
al.,1989). Despite protests to the contrary (Robinson et al., 2004; Saks, 2006), employee engagement as measured in industrial settings is not completely distinct among measures of organizationally based self-esteem and other measures of job involvement including organizational commitment. While there are many measures of all these constructs, all emphasize, in one way or another, the employee's perception of his/her value to the organization, the employee's loyalty and commitment to the organization, and his/her willingness to contribute to the good of the organization.

There are differences however. OBSE, for example, is deemed part of an employee's basic belief system such as "I count around here" (Pierce et al., 1989), while OC assesses "behavioral intention variables," such as being willing to exert discretionary effort and have the intention to stay with the organization (Pierce \& Dunham, 1987, p. 167). Employee engagement per se embodies several of these concepts and includes affective, behavioral, and cognitive dimensions of job involvement (Kahn, 1990). Most importantly, both OBSE and OC are reportedly trait-oriented, or stable over time (Mowday et al., 1979; Pierce et al., 1989), while employee engagement is believed to be state-oriented, i.e., modifiable on the basis of changes in job conditions. It is this latter characteristic of industrial employee engagement measures that has most attracted business leaders and made employee engagement one of the bandwagon concepts over recent decades (Frank, Finnegan, \& Taylor, 2004). Wefald and Downey (2009) suggest that the concept has been around too long to be a fad but questions the extent to which employee engagement has permeated academic research. Not entirely enthusiastic, these authors suggest that much more work is needed with both industry and academic measures of engagement, in its current incarnation, before we can know whether it is "fad, fashion or folderol" (p. 141). 
Kahn (1990), who was one of the early academic researchers to define the concept of employee engagement per se, viewed engagement as the "harnessing of organizational members' selves to their work roles; in engagement, people employ and express themselves physically, cognitively, and emotionally during role performances" (p. 694). Generally, engaged employees are those who have "a sense of energetic and effective connection with their work activities and they see themselves as able to deal completely with the demands of their job" (Schaufeli et al., 2002, p. 73). According to Glaspie and Nesbitt (2004) "Simply put, fully engaged employees are those who go beyond what their job requires, putting in extra effort to make the company succeed" (p. 1). Pertinent to the social exchange theory that frames this research, Angle and Perry (1983) suggest that this type of "harnessing" of the self is a function of the way that the employee has been treated by the organization.

Research suggests that workers who are engaged tend to be less stressed and more satisfied with their personal lives; they also tend to use less health care, take fewer sick days, be more productive, and stay longer with their organizations than their less engaged counterparts (Gallup Organization, 2003; 2006). Still, there are too few empirical studies of employee engagement as defined in the practitioner literature to be making such broad claims. Moreover, of the studies that do exist, too many of them are conducted with younger employees and professionals; older workers are all but ignored (Robinson et al., 2004). Indeed, we found only a few studies that tested age as a factor in employee engagement. Robinson et al. (2004), for example, found that workers over the age of 60 were the most engaged among all ages of employees (see also, Stagner, 1985, who reported that older workers were more likely to be higher in job involvement; and Pitt-Catsouphes \& Matz-Costa, 2009, who found that older workers were more engaged than younger workers). Yet, as mentioned, the perception persists 
that older workers are "checked out" or just marking time until retirement, i.e., not engaged (Stagner, 1985; Hedge et al., 2006).

Why Might Older Workers be Differently Engaged in Work than Younger Workers?

As today's elders live longer and remain healthy for longer periods of time than did previous generations, current cohorts of older workers are facing new pressures to delay retirement, which means older workers are being added to the workplace culture (Munnell \& Soto, 2005). Some of these older employees continue to work because they enjoy it and need the meaning, structure and life purpose that work provides (Moen \& Altobelli, 2007; Smyer \& PittCatsouphes, 2007). Others continue work in order to maintain costly health benefits and/or to supplement inadequate pensions (Munnell \& Sunden, 2004). Some, of course, work because they can ill afford retirement at all (Brown, Jackson \& Faison, 2007; Sorensen, 2007). A study published by AARP (Brown, 2003) revealed that nearly $70 \%$ of workers over 45 say they plan to work in their retirement years; these numbers are expected to grow in the current economic climate.

Older workers, especially those who are approaching conventional retirement ages, might be different on the basis of pre-conceived notions that they are not expected to be working still, and if they are working, to be marking time until they can retire (Kite, Stockdale, Whitley, \& Johnson, 2005). From this perspective, older workers might be less engaged than younger workers, feeling that, in terms of the reciprocity norm, they have fulfilled their end of the bargain by the time they reach their later years. From another perspective, today's older workers are said to embrace a different psychological contract than do younger workers in that older workers expect job security and regular pay increases in exchange for loyalty (D’Amato \& Herzfeldt, 2008). In this view older workers would be more engaged than younger workers. In confirmation 
of the latter view, one recent study that examined age as a factor in employee engagement showed that, while engagement generally decreased with age, this pattern reversed at age 60 , with over 60 workers reporting the highest levels of engagement (Robinson et al., 2004). Even though there is a burgeoning interest in generational differences in work-related attitudes and values including organizational commitment and engagement (Cennamo \& Gardner, 2008; D'Amato \& Herzfeldt, 2008; Twenge \& Campbell, 2008), too few studies include workers who are beyond conventional retirement ages for comparison. More research is needed to estimate the extent to which older workers are likely to be more or less engaged than their younger counterparts.

More important than whether they are more or less engaged than younger workers is the question of what job conditions are associated with greater engagement on their parts. The question of what older workers want from employers in the psychological contract is hard to answer. First, as mentioned, they are not a homogeneous group; there are many differences among them. Some want "bridge jobs," (Cahill, Giandrea, \& Quinn, 2007); some want phased retirement (Hutchens \& Grace-Martin, 2005); and some want promotions (Helson \& Cate, 2007). Second, there is a lack of scientific evidence to inform the development of measures that will capture job resources that are important to older workers in the changing contexts that we have described in terms of increased longevity, continued health, and extensions to the work years (James \& Wink, 2007). For the research presented here, we relied on job quality factors that may play a role in employee engagement at all ages. We included a wide range of job quality measures developed for workers of no specified age as described by Johnson and Hall (1988) and Karasek (1979), including supervisor support, on-the-job-autonomy, and schedule flexibility (Swanberg, James, Werner \& McKechnie, 2008). We also assessed factors such as opportunities 
for development that may be particularly important to older workers (Christensen, 2006; PittCatsouphes \& Smyer, 2006), and knowledge about some of the challenges and difficulties confronting older people who want to stay employed, such as perceptions of fairness (Kite \& Wagner, 2004).

One of the most persistent of preconceived notions about older workers is the belief that they are not interested in training and development opportunities based on the same bias mentioned above that they are "checked out," or worse, "slow to learn," or difficult to train (Kite et al., 2005; Rosen \& Jerdee, 1976; Sterns \& Miklos, 1995). Indeed there are many negative perceptions of older workers' qualifications for work and desires for opportunities (Gordon, Arvey, Hodges, Sowanda, \& King, 2000, as cited in Hedge et al., 2006; Finkelstein, Burke, \& Raju, 1995) especially in the area of training (e.g., Novelli, 2002). As a result, older workers are often denied training opportunities (Farr, Tesluk, \& Klein 1998; Novelli, 2002).

Are older workers interested in training? According to Hedge et al. (2006) some research has shown that older employees are interested in training (Hale, 1990). Some researchers find intensive interest (Simpson, Geller, \& Stroh, 2002); some find that older workers are more interested in "training off the job" (Peterson \& Wendt, 1995). Some find that employees are only interested in training that is job-related (Warr, 2001). "The low interest level of older workers for many in-house training programs may say more about the content of those programs, their job relevance, and the degree of comfort they afford older trainees than it does about older workers' general interest in training" (Hedge et al., 2006, p.139).

Central to the research presented here is the extent to which opportunities for training and development create the impression that the organization is exerting discretionary effort on behalf of employees such that they are impelled to return the favor. On the basis of social exchange 
theory, if older workers truly are not interested in training, the lack of it will have little impact on their levels of engagement. If they are interested, then such opportunities may be construed as other indicators of the organization's discretionary effort toward the employee that may convey a supportive environment and inspire the employee to give back to the organization in kind. "To the extent that both the employee and the employer apply the reciprocity norm to their relationship, favorable treatment received by either party is reciprocated, leading to beneficial outcomes for both"(Rhoades \& Eisenberger, 2002, p. 698).

Another way that older workers might differ from younger workers is in their attitudes toward work. As we have mentioned, many older workers indicate that they do want to work longer, but they may want to work in different ways. Some researchers have suggested that older workers tend to prefer flexible schedules, fewer hours, and other work conditions that are more responsive to their particular needs (Barth, McNaught, \& Rizzi, 1995; Greller \& Stroh, 2003; Hedge et al., 2006; Shultz, 2003). Thus, the provision of flexibility for older workers may be a highly valued job condition that makes these workers feel obligated to give back or reward the organization with higher engagement. Some support for this theory was provided by PittCatsouphes and Matz-Costa (2008) who, using data from more than 20 organizations, found that having the right kind of job flexibility ("flexibility fit") was more important to older workers than to younger workers and in fact, significantly predicted employee engagement (see also Muller and Knapp, 2003).

Older workers, in addition to flexibility on the job, may want different things from work. According to Hedge et al. (2006):

"Older employees continue to work for reasons other than the need for income and benefits. Indeed, it is often noted that in midlife workers begin to place more emphasis on 
intrinsic rewards from work, such as a feeling of accomplishment, of learning and experiencing new things, and of doing something worthwhile... (p. 122).

Therefore, it is clear that research to date has provided some insights into the job conditions that older workers seem to care about, but little to no assessment of the extent to which employers who satisfy the wish list are rewarded with greater engagement by these older employees.

\section{Job Quality, Employee Engagement and Older Workers}

We have been unable to locate any research about the job conditions that are associated with employee engagement of older workers in a retail setting even though retail is the secondlargest industry in the U.S. with over 15 million employees (U.S. Department of Labor, 2007). There are currently more than 25 million older workers in the U.S (U.S. Department of Labor, 2007), and retail appears in the top ten industries employing workers 65 and older in 10 of the 12 states' reports published to date (U.S. Census Bureau, 2007). Thus, we have used the data from a national retail chain to explore the job conditions that predict employee engagement among several groups of older and younger workers, both exempt and non-exempt, categorized according to different norms and expectations about work at different points in the life cycle.

Our broad research questions are: (1) Does employee engagement differ on the basis of age; (2) What job-quality factors predict employee engagement; and (3) Do the effects of these factors vary by age?

\section{Method}

This study was conducted as part of a larger organizational research project focused on understanding the meaning of job quality and its impact on employee engagement among different populations of workers employed by the retailer, CitiSales (a pseudonym). CitiSales is a 
large, national Fortune 500 retail firm with over 6,000 stores across the U.S. and has recently adopted a strategic commitment to creating an organizational culture that engages older workers. Participants

All employees $(\mathrm{N}=8433)$ in 352 stores in 3 regions of the U.S., two in the Midwest and one in the Southeast, were invited to participate in this study; 6085 employees representing all ages and occupational categories participated, yielding a $72 \%$ response rate. Of the surveys collected, 6,047 were usable, leaving us with a final sample of 6,047. Table 1 presents the demographics for all of the groups of employees in the sample, both in total and within each age category.

Procedure

Paper surveys were mailed via overnight mail by a data management firm to the store managers of all 353 stores. Managers were asked to distribute the surveys with a return envelope addressed to the data management firm to all employees in the store. The introduction to the survey specified that the study was designed to learn more about the lives of American workers and their experiences at work that affected them and their families. Participants were allowed company time to fill out the survey, which took approximately 10-12 minutes. Participants were also invited to participate in a lottery that awarded two $\$ 500$ prizes, five $\$ 100$ prizes, and $10 \$ 50$ prizes. After two weeks, reminders were sent to the stores encouraging people to return the surveys. As noted above, we received wide cooperation.

\section{Measures}

Age Categories. Our determination of age distinctions was informed by Sterns and Miklos (1995). We have chosen to embrace the life-span approach which includes elements of all five approaches recommended by Sterns and his colleagues. We therefore use knowledge of 
age norms and expectations about work and career cycles to interpret five age intervals. As such we break our sample into three groups of younger workers and two groups of older workers. The three groups of younger workers are: ages 18-24, i.e. “emerging adults," (Arnett, 2004), also referred to as the "youth labor force," (Lowe, 2001); ages 25-39, "settling in" adults, those who are becoming self sufficient, making commitments (Arnett, 2004); and adults in their "prime working years" (ages 40-54) i.e. the years when almost everyone works (Sterns \& Huyck, 2001). The two groups of older workers include those aged 55-65 i.e., the years when retirement looms, those who are "approaching retirement" (James \& Spiro, 2007), and a group of employees age 66 and above, all of whom in today's context are eligible for retirement, "retirement eligible." In fact the general expectation for workers 66 and older is that they are retired (James \& Wink, 2007). Thus, these workers may be employed by choice more so than other workers. We examine differences among these five groups in employee engagement.

Dependent Variable. Employee engagement was assessed using a measure that was developed for CitiSales by a vendor; representatives of the company modified the measure and used it for prior in-house research. The eight items in the scale, in terms of face validity, measure the cognitive, emotional, and behavioral aspects of engagement. Employees were asked the extent to which they agreed or disagreed (on a 5-point likert scale) with the following questions: (1) cognitive questions: "It would take a lot to get me to leave CitiSales"; "I would like to be working for CitiSales one year from now"; "Compared with other companies I know about, I think CitiSales is a great place to work;" (2) emotional questions: "I really care about the future of CitiSales"; "I feel like I am an important part of CitiSales"; "I feel like my work makes an important contribution to CitiSales' success"; and behavioral questions: "I would highly 
recommend CitiSales to a friend seeking employment"; "I am always willing to give extra effort to help CitiSales succeed." Cronbach's alpha for the scale was .91.

Independent Variables. The survey included 27 questions related to several known aspects of job quality, such as supervisor support, the extent to which the employee has autonomy on the job and/or too much red tape, schedule input and flexibility, career development opportunities, and perceptions of fairness in the treatment of different types of employees. Employees were asked the extent to which they agreed or disagreed (on a 5-point likert scale) with each statement. Exploratory factor analysis, utilizing principal components analysis and varimax rotation, was then used to identify commonalities among the variables (examination of our data indicated that they satisfied the requirements for this type of analysis). We identified those factors with acceptable internal consistency using Cronbach's alpha and then used the summed, standardized factor scores from those factors to build our job quality variables. The factors, eigenvalues, variance explained, Cronbach's alphas, and the variables that comprise them are shown in Table 2. Four of the six factors had acceptable internal consistency $(\alpha \geq 0.7)$ which we labeled "Supervisor Support \& Recognition”, "Schedule Satisfaction”, “Career Development \& Promotion", and "Job Clarity" respectively. The final two factors (labeled "Intrinsic Job Satisfaction" and "Fairness"), did not meet acceptable standards for internal consistency and were not included in any analyses.

Control Variables. Although our focus was the effects of the job quality factors on employee engagement, we also identified a set of control variables that might have a bearing on our findings to include in the analyses including: gender, education level, marital status, parttime or full-time employed, and whether the employee is paid hourly or salaried. In each of these 
cases our data comprised categorical variables; therefore dummy variables were created and used in the regression analyses.

\section{Results}

One way analysis of variance (ANOVA) was used to identify differences in employee engagement among the five age groups. The ANOVA indicated that there were significant differences among the groups, $F(4,5076)=31.41, p<.001$; we then used post hoc pairwise comparisons of the group means with the Bonferroni multiple comparison adjustment of the pvalues to identify what group means differed from what other group means. These results, presented in Table 3, show that the younger the employee the less engaged they are. Those aged 24 and younger, the emerging adults, had a mean employee engagement score of 31.17 , which was significantly lower than that of the settling-in adults, ages $25-39, t(3249)=4.41, p<.001$, which in turn was significantly less than those in their prime working years, ages $40-54, t(2824)$ $=4.74, p<.001$. The emerging adults were also significantly less engaged than those approaching retirement, $t(2117)=8.17, p<.001$, and those who were retirement eligible, $t(1758)=5.63, p<$ .001. Similarly, the settling-in adults were significantly less engaged than those employees who were approaching retirement, $t(2112)=5.17, p<.001$, and also those who were retirement eligible, $t(1753)=3.92, p<.001$. There were no significant differences among the mean employee engagement scores for the three older groups. ${ }^{1}$ The means and variance of employee engagement for each of the age categories are illustrated in box plots in Figure 1.

We then used linear regression analyses to estimate the effects of the job quality factors on employee engagement. Table 4 presents the correlation coefficients for the variables included

\footnotetext{
${ }^{1}$ To ensure that differences in employee engagement were associated with employees' age and not their length of tenure at CitiSales we ran an additional ANOVA including both age and tenure. The results of this analysis showed that although age did have a significant effect on the variance of the employee engagement measure $F(4,5043)=$ $8.74, p<0.01)$, tenure was not a statistically significant predictor $F(5,5042)=2.16, p>0.05)$
} 
in this analysis. We conducted a separate regression analysis for each of our five age categories, with the results presented in Table 5. Since large sample sizes are likely to produce more significant, but meaningless results, we present both the $\mathrm{R}^{2}$ and Cohen's $f^{2}$ for each model. The larger the value of $f^{2}$ the larger the predictive power of the independent variables and their multiple correlation with the dependent variable; since all effects are at least medium-sized, our findings appear to be meaningful even though we have a large sample.

The results indicate that the five control variables have stronger effects on employee engagement for the emerging and settling-in adults than for the prime-working-years group, the approaching-retirement group and the retirement-eligible group. For instance, emerging adults were likely to be more engaged if they were female $(\beta=1.02, p<0.001)$. Workers in this age category were less engaged if their education included 2-year or some college $(\beta=-1.05$, $p<0.001)$ or if they had attained a bachelor's degree or above $(\beta=-2.10, p<0.001)$, and if they were hourly rather than salaried employees $(\beta=-1.26, p<0.01)$. Findings were similar for settling-in adults aged 25-39, except gender was not related to employee engagement, and only those educated to a bachelor's degree or above were less engaged than those with a high school diploma or equivalent $(\beta=-2.65, p<0.001)$. In both the approaching-retirement and the retirement-eligible groups, the only control variables that had a significant effect on engagement were gender and employment status; this was also true for the prime working-years group. For this latter group of employees aged $40-54$, females were more engaged than males $(\beta=1.32$, $p<0.01$ ), while employees who are approaching retirement (aged 55-65) who worked part-time were less engaged than those employed full time $(\beta=-1.82, p<0.001)$. There were no significant effects from the control variables for the oldest or retirement-eligible group. 
Three of the job quality factors had significant, positive effects on employee engagement across all of the age/career categories. These three factors were; Supervisor Support \& Recognition, Schedule Satisfaction, and Job Clarity, and these results answer our second research question: what job quality factors predict employee engagement. Whereas, all four factors were significantly related to engagement for the 3 groups of younger employees along with the approaching-retirement group $(p<0.001)$, one factor, Career Development \& Promotion was not related to employee engagement for the retirement-eligible group (66 and older). These findings provide a partial answer to our second research question, indicating that the effects of the factors do vary somewhat by age of the employee.

We identified effect-size differences in the independent variables on the dependent variable using the standardized coefficient, $\beta$; results indicated that there are differences in the effects of the job quality dimensions among age/career-stage groups. Supervisor support and recognition had by far the largest effect on employee engagement for the two groups of older employees, those who are approaching retirement, aged 55-65, $(\beta=0.41, p<0.001)$ and those who are retirement-eligible, aged 66 and over $(\beta=0.50, p<0.001)$. However, for those in the youngest two groups (both emerging- and settling-in adults), career development and promotion had the strongest effect on engagement, $(\beta=0.44, p<0.001)$ and $(\beta=0.40, p<0.001$, respectively). The differences among the various age groups in the importance of Career Development versus the importance of Supervisor Support and Recognition can be seen in the results of primeworking-years employees aged 40-54, where the $\beta$ scores for those two factors are almost equal: Supervisor Support $\beta=0.38, p<0.001$, and Career Development and Promotion $\beta=0.37, p<0.001$, Job Clarity had the third strongest effect for all but the retirement-eligible employees $\beta=0.23$, $p<0.001$, including emerging-adult employees aged 24 and under, $\beta=0.28, p<0.001$, for settling- 
in adults aged $25-39, \beta=0.29, p<0.001$, for prime-working-years adults, aged $40-54, \beta=0.38$, $p<0.001$, and for adults who are approaching retirement, aged 55-65 $\beta=0.38, p .<0.001$.

Similarly, Schedule Satisfaction had the least effect on employee engagement for all but the retirement-eligible employees--for emerging adults, $\beta=0.17, p<0.001$; for settling-in adults, $\beta=$ $0.16, p<0.001$; for those in their prime working years, $\beta=0.15, p<0.001$; and for the approaching-retirement group $\beta=0.13, p<0.01$. In contrast, Schedule Satisfaction appeared to be much more important for retirement-eligible employees aged 66 and over $\beta=0.33, p<0.01$, with Career Development and promotion having the lowest (and non-significant) effect on engagement $(\beta=0.10, p=.417)$.

\section{Discussion}

The issue of age in the workplace has been said to be the "new diversity" as more workers extend their working lives beyond the conventional retirement ages of 62-65 and reshape organizational life (Capowski, 1994). Organizational leaders have been urged to develop "new competencies" for managing and retaining this rather new demographic group (Cappelli, 2003). With data from a national retail chain environment comprised of a large sample of workers of all ages, and an unusually large group of these older workers, we were able to estimate the extent to which different job conditions predicted employee engagement for older workers compared to their younger counterparts while also examining finer-grained differences among employees at different points in the cycle of their careers. Our findings show that although older workers are significantly more engaged than their younger colleagues, older workers are not dramatically different from younger workers in the job conditions that predict employee engagement. While there was evidence of difference in the ranking of the factors 
related to specific job conditions, the factors that predicted employee engagement, with one exception, were the same.

Our study is one of just a few current studies that have a sufficient sample of workers over the age of 55 and over 65 to assess differences in employee engagement across the life span. In keeping with Robinson et al., (2004) our findings do not support the idea that older workers are "checked out," or marking time until retirement; indeed both the approaching-retirement, and the retirement-eligible employees are more engaged than are the younger workers. As expected on the basis of other research indicating that emerging adults are still in transition to adult roles and commitments (Arnett, 2004), these employees were the least engaged of all the groups. In terms of the reciprocity norm, older workers may have different expectations about work and their relationship to their supervisor than do younger workers. Research implies that older workers may represent a generation of employees who believe that they will be rewarded for their loyalty (D’Amato \& Herzfeldt, 2008). Sometimes called “Traditionalists," these workers are said to be highly obligated to the organizations that hire them and to manifest a strong work ethic or job-related behaviors that benefit the leader (Harrington \& Hall, 2007).

Given the finding that older workers are more engaged than younger workers, it is interesting to note that the factors that predict engagement do not differ by age group (with the exception of Career Development and Promotion, which appears to be less important to the retirement-eligible employees). Both older and younger workers (all groups) who perceive their supervisors to be supportive and concerned about their well-being, and who recognize them for their accomplishments, are more engaged than those who do not experience this level of support. Like other researchers (Wayne et al., 1997) we found that, supervisors who express concern for the well-being of employees of all ages across the life span, from ages 18 to over 65 , and give 
them recognition for a job well done, can expect to be rewarded with reciprocal actions that benefit the supervisor. In addition, both older and younger workers who experience job clarity are more engaged than those who do not.

Both older and younger workers who feel satisfied with their schedules and who have the flexibility they need to manage both work and personal responsibilities are more engaged than those who feel their schedules do not fit with competing responsibilities. The value of flexible work arrangement to employees of all ages is now well documented (Kelly et al., 2008; Swanberg et al., 2008), and flexible workplaces are "all the rage" (Pitt-Catsouphes, Matz-Costa, \& Besen, 2009). Organizations, however, are still trying to find ways to implement these practices in ways that benefit the business as well as the employee (Van Deusen, James, Gill, \& McKechnie, 2008; Swanberg et al. 2008). Pitt-Catsouphes \& Matz-Costa (2008) and Swanberg et al. (2008) suggest, however, that making such options available to employees is in fact good for the business, and is perceived as an especially valuable job condition for older workers (PittCatsouphes \& Matz-Costa, 2008). These findings, taken together, suggest that employees of all ages who have schedule satisfaction and flexibility will reward the organization with higher engagement.

Older workers up to the retirement-eligible age of 65 and their younger counterparts who feel that they have sufficient access to career development and opportunities for promotion are more engaged than those who feel passed over for these chances. On the other hand, career development opportunities are not a significant factor in employee engagement for those employees who are retirement eligible. Perhaps these are workers who consider employment at this point in their lives as either a "bridge job" or a job to structure their time in a productive way, or a good way to phase in to retirement, or as a source of extra income; we can only 
speculate. Our findings of differences between the two groups of older workers highlight the need for further fine-grained studies of the differences within groups of older workers.

Although the link between development opportunities and engagement is stronger for younger employees, the relationship between these variables and age is in keeping with those of Robinson et al., (2004) and challenges the myth that older workers, at least those in late midlife, are disinterested in opportunities for growth and learning. Perhaps the message for managers, rather than tooling up on new competencies for managing older workers, is to overcome damaging and pernicious perceptions that they are less energetic about the work and disinterested in learning (McCann \& Giles, 2002). Indeed, they seem to find meaning and purpose in the work (James, Swanberg \& McKechnie, 2007). In accordance with social exchange theory, opportunities for learning, and yes, even promotions, provided for employees who are approaching retirement ages and younger workers alike, may be construed as indicating discretionary effort toward the employee that is then rewarded with discretionary effort on the job.

There were, however, differences between older and younger workers in terms of the ranking of the factors from the most to the least important in relation to engagement. These differences among the age groups suggest that some of the generational differences that have been discussed in the research literature may be operating among CitiSales employees (see, for example, Smith, 2008).

As mentioned, current cohorts of older workers, especially the retirement-eligible group, for instance, are said to be more oriented toward authority and more loyal to the organization than are younger workers (D'Amato \& Herzfeldt, 2008). In short, they believe that loyalty to the organization pays off. On the other hand, younger employees of today are said to feel more 
personally responsible for their careers as opposed to expecting organizational representatives to lead the way. As suggested by Kossek and Lautsch (2008), they become the "CEO of me" by taking responsibility for pursuing training and development opportunities to build a career and/or find meaningful work on their own terms. In the process, they are more likely to transition from one job to another in pursuit of their career goals. Thus, the higher engagement levels of the two groups of older CitiSales workers may be due to the fact that when they have supervisor support and clarity about what the supervisor is looking for, it is easier for them to align their goals with his or hers. In contrast, younger workers are more interested in getting the training and development they need to support future moves and are more engaged when they have intrinsic satisfaction i.e., find the job interesting, challenging, and personally meaningful. Thus, the findings suggest that managers worry less about engaging the "new" older worker, and maximize training and development opportunities for these younger workers who might then be more likely to stay.

Overall our findings are very much in line with the general tenets of social exchange theory, except for the finding that perceived fairness was not a valid factor, and therefore was not included in the final analyses. This discrepancy may be due to the fact that unfairness in terms of promotions or who gets ahead or when time is taken for family responsibilities is not strongly felt at CitiSales. This is plausible, as the organization endeavors to ensure flexibility wherever possible for its employees (Swanberg et al., 2008). In addition, this organization has been recognized by the AARP as a preferred employer of older workers. It may be that these particular aspects of unfairness are not paramount for employees in this setting, or that store managers have been trained to minimize perceived differences between employees on the basis 
of age. It may also be the case that older workers persevere and stay engaged even when promotion and advancement are not forthcoming.

\section{What do Findings Suggest about the Measurement of Employee Engagement?}

We have argued that the measure of employee engagement used here is similar to but subtly different from constructs such as job involvement, organizational commitment, and organizationally based self esteem. Thus, managers may well want to substitute well-validated and equally good measures such as the organizational commitment scales (e.g., Mowday et al., 1979); organizational self-esteem scales (e.g., Pierce et al., 1989), and job involvement scales (e.g., Newton \& Keenan, 1983), for newer, but generally expensive proprietary instruments. Since we cannot resolve this issue, we suggest that future research systematically examine the relationships among these older instruments alongside the vendor-based measure that we used.

Hallberg and Schaufeli (2006), for example, use confirmatory factor analyses to show that the Utrecht Work Engagement Scale (UWES) is both conceptually and empirically distinct from measures of job involvement (Sjbert \& Sverke, 2000, as cited in Hallberg \& Schaufeli, 2006) and organizational commitment (Meyer \& Allen, 1991, as cited in Hallberg \& Schaufeli, 2006). On the other hand, these authors also view the UWES as a "trait-oriented" measure of engagement.

As we have mentioned, employers tend to prefer the more malleable "state-oriented" measures because they reason that such assessments reveal areas of needed change; once revealed, actions on the part of the employer can increase the employee engagement (Wefald \& Downey, 2009). Leaders at CitiSales maintain the latter view of the measure used for this study. The fact that engagement varies on the basis of several aspects of job quality suggests that it is indeed state-oriented and that managers are justified in using findings to make on-the-job 
adjustments that may increase the engagement levels of their employees. Again, we leave this question to future research.

\section{Summary and Conclusions}

On the whole, our study makes several contributions to the literature. First, as mentioned, it is the only study we know of that has examined employee engagement as measured by practitioners in a retail setting across a wide range of ages. As such it answers repeated calls for more effective collaboration between academic researchers and practitioners (Bartunek, 2007; Wefald \& Downey, 2009). Second, it adds complexity to discussions of older and younger workers by highlighting meanings attached to work within both of those groups by examining job quality factors at different points in the life of a career. Although employees are more similar than different in the job conditions that predict employee engagement, the differences identified suggests that age matters and that employers should be thinking more about age as the new diversity issue. Finally, our study indicates that the unique requirements of younger workers are just as crucial to making employees feel energized and engaged as are those of the older workers. Recognition that there are age issues to attend to across the life span should obviate the concern that employers, who are trying to recruit and retain older workers, leave themselves vulnerable to complaints of unfair preferences.

There are, however, important limitations to our study. We studied one company, albeit with a sample encompassing three different regions, with a largely female workforce; we do not know whether our results would extend to other types of organizations or workers. In addition, as mentioned, the company we studied has been recognized for its commitment to older workers by AARP; perhaps our results are more positive than they would be in a company without such recognition. 
Further, as our study is exploratory in nature, we focused in this instance on broad aspects of job quality and employee engagement among three groups of younger workers, and two groups of older workers; in doing so, we may have overlooked some fine-grained differences both within the groups and between them. Neither can we be certain of the effects of age on employee engagement; longitudinal data are needed to disentangle age, period and cohort effects. We leave it to future researchers to fine tune additional job factors important to engaging both older and younger workers and conduct longitudinal research with these concepts. Such work is important to both researchers and practitioners alike as a new cohort of young workers moves into the workplace while the conventional retirement age is becoming almost irrelevant (Munnell \& Soto, 2005).

Despite these limitations, our findings suggest that managers would do well to shed preconceived notions about older workers and focus scarce resources on the development of supervisors who provide both recognition and support for the well-being of employees of all ages. Supervisors who strive to create such favorable job conditions as clarity about expectations and roles, flexible schedules, and jobs that fit with employee skills and interests in a way that makes the job intrinsically satisfying are likely to experience a reciprocal concern for the welfare of the organization from employees. These job conditions would seem to be a kind of "emotional paycheck," or job conditions that inspire positive emotions (Siebert, 2006).

Our findings support the notion within social exchange theory, that such discretionary efforts of the part of the organizational representative are rewarded with engaged and productive workers, a highly desirable state especially in tough economic times. Although some awareness of shades of difference across current cohorts of employees at different points in the career cycle might be useful for managers, our findings do not suggest the need for re-tooling. In the sense 
that both older and younger workers may be susceptible to stereotyping (James, Pitt-Catsouphes, \& Matz-Costa, 2008), overcoming age-related stereotypes may be the best end goal, rendering "age" in all its complexity and multiple meanings as important elements in any diversity training efforts. 


\section{References}

Angle, H. L., \& Perry, J. L. (1983) Organizational commitment: Individual and organization influences. Work and Occupations, 10, 123-146. doi: 10.1177/0730888483010002001

Arnett, J. J. (2004). Emerging adulthood: The winding road from the late teens through the twenties. New York, NY: Oxford University Press, Inc.

Baltes, P. B., Reese, H. W., \& Libsitt, L. P. (1980). Life-span development psychology. Annual Review of Psychology, 31, 65-110. doi: 10.1146/annurev.ps.31.020180.000433

Barth, M. C., McNaught, W., \& Rizzi, P. (1995). Older Americans as workers. In S. A. Bass (Ed.), Older and active: How Americans over 55 are contributing to society (pp.35-70), New Haven, CT: Yale University Press.

Bartunek, J. M. (2007). Academic-practitioner collaboration need not require joint or relevant research. Toward a relational scholarship of integration. Academy of Management Journal, 50(6), 1323-1333.

Belbin, J. E. (1965). Training methods for older workers. Paris, France: OECD.

Brown, E., Jackson, J. S., \& Faison, N. A. (2007). The work and retirement experiences of aging black Americans. In J. James \& P. Wink (Eds.), The crown of life: Dynamics of the early postretirement period (pp. 39-60). In K.W. Schaie, (Series Ed.), Annual Review of Gerontology and Geriatrics, 26. New York, NY: Springer Publishing Co.

Brown, S. K. (2003). Staying ahead of the curve 2003: The AARP working in retirement study. Washington, DC: AARP.

Burchett, B. M. (2005). Employment discrimination. In E. B. Palmore, L. Branch, \& D. K. Harris, (Eds.), Encyclopedia of ageism (pp. 122-125). New York, NY: The Haworth Press. 
Burtless, G., \& Quinn, J. F. (2002). Is working longer the answer for an aging workforce? (Issue Brief No. 11). Chestnut Hill, MA: The Center for Retirement Research at Boston College. Retrieved from http://crr.bc.edu/images/stories/Briefs/ib_11.pdf

Cahill, K. E., Giandrea, M. D., \& Quinn, J. F. (2007). Down shifting: The role of bridge jobs after career employment. (Issue Brief No. 6). Chestnut Hill, MA: Boston College Center on Aging \& Work/Workplace Flexibility. Retrieved from http://agingandwork.bc.edu/documents/IB06_DownShifting_003.pdf

Capowski, G. (1994). Ageism: The new diversity issue. Management Review, 83(10), 10-15.

Cappelli, P. (2004). Will there really be a labor shortage? Public Policy and Aging Report. 14(3), 1, 3-6. doi: 10.1002/hrm.20056

Cennamo, L., \& Gardner, D. (2008). Generational differences in work values, outcomes and person-organization values fit. Journal of Managerial Psychology, 23(8), 891-906. doi: $10.1108 / 02683940810904385$

Chalofsky, N., \& Krishna, V. (2009). Meaningfulness, commitment, and engagement: The intersection of a deeper level of intrinsic motivation. Advances in Developing Human Resources, 11, 189-203. doi: 10.1177/1523422309333147

Christensen, K. (2006). Leadership in action: A work and family agenda for the future. In M. Pitt-Catsouphes, E. E. Kossek, \& S. Sweet (Eds.), The work and family handbook (pp. 705-734). Mahwah, NJ: Lawrence Erlbaum.

D’Amato, A., \& Herzfeldt, R. (2008). Learning orientation, organizational commitment and talent retention across generations. A study of European managers. Journal of Managerial Psychology, 23(8), 929-953. doi: 10.1108/02683940810904402 
DeLong, D. W. (2004). Lost knowledge: Confronting the threat of an aging workforce. New York, NY: Oxford University Press.

Dennis, H. (Ed.) (1988). Fourteen steps in managing and aging work force. Lexington, MA: Lexington Books.

Dohm, A., \& Shniper, L. (2007). Occupational employment projections to 2016. Monthly Labor Review, 13(11), 86-125.

Eisenberger, R., Huntington, R., Hutchison, S., \& Sowa, D. (1986). Perceived organizational support. Journal of Organizational Behavior, 71(3), 500-507. doi: 10.1037/00219010.71.3.500

Farr, J. L., Tesluk, P. E., \& Klein, S. R. (1998). Organizational structure of the workplace and the older worker. In K. Schaie \& C. Schooler (Eds.), Impact of work on older adults (pp. 143-185). New York, NY: Springer Publishing Company.

Finkelstein, L. M., Burke, M. J., \& Raju, N. S. (1995). Age discrimination in simulated employment contexts: An integrative analysis. Journal of Applied Psychology, 80, 652663. doi: $10.1037 / 0021-9010.80 .6 .652$

Frank, F. D., Finnegan, R. P., \& Taylor, C. R. (2004). The race for talent: Retaining and engaging workers in the $21^{\text {st }}$ century. Human Resource Planning, 27, 12-25.

Gallup Organization (2003). Bringing work problems home. Gallup Management Journal, Retrieved from http://gmj.gallup.com.

Gallup Organization (2006). Gallup study: Engaged employees inspire company innovation. Gallup Management Journal, Retrieved from http://gmj.gallup.com. 
Gilboa, S., Shirom, A., Fried, Y., \& Cooper, C. (2008). A meta-analysis of work demand stressors and job performance: Examining main and moderating effects. Personnel Psychology, 61, 227-271. doi: 10.1111/j.1744-6570.2008.00113.x

Glaspie, P., \& Nesbitt, M. (2004). Employee engagement: Readership Institute report. Evanston, IL: Northwestern University.

Greller, M. M., \& Stroh, L. K. (2003). Extending work lives: Are current approaches tools or talismans? In G. A. Adams \& T. A. Beehr (Eds.), Retirement; Reasons, processes, and results (pp. 115-135). New York, NY: Springer Publishing Company.

Griffin, M. A., Neal, A. \& Parker, S. K. (2007). The new model of work role performance: Positive behavior uncertain and interdependent contexts. Academy of Management Journal, 50, 327-347.

Hale, N. (1990). The older worker: Effective strategies for management and human resource development. San Francisco, CA: Jossey-Bass.

Hallberg, U. E., \& Schaufeli, W. B. (2006). "Same same” but different? Can work engagement be discriminated from job involvement and organizational commitment?. European Psychologist, 11, 119-127. doi: 10.1027/1016-9040.11.2.119

Harrington, B., \& Hall, D. T. (2007). Career management \& work-life integration: Using selfassessment to navigate contemporary careers. Thousand Oaks, CA: Sage Publications, Inc.

Havighurst, R. J. (1954). Flexibility and the social roles of the retired. American Journal of Sociology, 59, 309-311. doi: 10.1086/221362 
Hedge, J. W., Borman, W. C., \& Lammlein, S. E. (2006). The aging workforce: Realities, myths, and implications for organizations. Washington, DC: American Psychological Association.

Helson, R. \& Cate, R. (2007). Late middle age: Transition to the third age. In J. James \& P. Wink (Eds.), The crown of life: Dynamics of the early postretirement period (pp. 83101). In K.W. Schaie, (Series Ed.), Annual Review of Gerontology and Geriatrics, 26. New York, NY: Springer Publishing Co.

Herman, R., \& Gioia, J. (2003). Impending crisis: Too many jobs, too few people. Winchester, VA: Oakhill Press.

Hutchens, R. \& Grace-Martin, K. (2005). Employer willingness to permit phased retirement: Why are some more willing than others? Industrial and Labor Relations Review, 59 (4), $525-546$.

James, J. B. \& Lachman, M. E. (1997). Charting the course of midlife development: An overview. In M.E. Lachman \& J. B. James (Eds.), Multiple Paths of Midlife Development (pp.1-20). Chicago: The University of Chicago Press.

James, J. B., Pitt-Catsouphes, M., \& Matz-Costa, C. (2008, November). Is age the new diversity issue affecting team performance? Paper presented at the annual meeting of the Gerontological Society of America, Washington, DC.

James, J., \& Spiro, A. (2007). The impact of work on the psychological health and well-being of older Americans. In J. James \& P. Wink (Eds.), The crown of life: Dynamics of the early postretirement period (pp. 153-174). In K.W. Schaie, (Series Ed.), Annual Review of Gerontology and Geriatrics, 26. New York, NY: Springer Publishing Co. 
James, J. B., Swanberg, J. E., \& McKechnie, S. P. (2007). Generational differences in perceptions of older workers' capabilities (Issue Brief No. 12). Chestnut Hill, MA: Boston College Center on Aging \& Work/Workplace Flexibility. Retrieved from http://agingandwork.bc.edu/documents/IB12 OlderWorkers\%20Capability.pdf

James, J.B., \& Wink, P. (2007). The third age: A rationale for research. In J. James \& P. Wink (Eds.), The crown of life: Dynamics of the early postretirement period (pp. xix-xxxii). In K.W. Schaie, (Series Ed.), Annual Review of Gerontology and Geriatrics, 26. New York, NY: Springer Publishing Co.

Johnson J., \& Hall, E. (1988). Job strain, work place social support, and cardiovascular disease: A cross-sectional study of a random sample of the Swedish working population. American Journal of Public Health, 78, 1336-1342.

Kacmar, K. M., \& Ferris, G. R. (1989). Theoretical and methodological considerations in the age-job satisfaction relationships. Journal of Applied Psychology, 74, 201-207. doi: $10.1037 / 0021-9010.74 .2 .201$

Kahn, W. A. (1990). Psychological conditions of personal engagement and disengagement at work. Academy of Management Journal, 33(4), 692-724. doi: 10.2307/256287

Karasek, R. A. (1979). Job demands, job decision latitude, and mental strain: Implications for job redesign. Administrative Science Quarterly, 24, 285-308.

Kelly, E., Kossek, E. E., Hammer, L. B., Durham, M., Bray, J., Chermack, K., Murphy, L., \& Kaskubar, D. (2008). Getting there from here: Research on the effects of work-family conflict and business outcomes. The Academy of Management Annals, 2(1), 305-349. doi: $10.1080 / 19416520802211610$ 
Kite, M. E., Stockdale, G. D., Whitley, B. E., \& Johnson, B. T. (2005). Attitudes toward younger and older adults: An updated meta-analytic review. Journal of Social Issues, 61(2), 241266. doi: 10.1111/j.1540-4560.2005.00404.X

Kite, M. E., \& Wagner, L. S. (2004). Attitudes toward older adults. In T. D. Nelson (Ed.) Ageism: Stereotyping and prejudice against older persons (pp.129-162). Cambridge, MA: The MIT Press.

Kossek, E. E., \& Lautsch, B. A. (2008). CEO of me: Creating a life that works in the flexible job age. Upper Saddle River, NJ: Wharton School Publishing.

Lachman, M. E. (Ed). (2001). Handbook of midlife development. New York, NY: Wiley \& Sons. Lockwood, N. R. (2007). Leveraging employee engagement for competitive advantage: HR's strategic role (SHRM Research Quarterly Report). Alexandria, VA: Society for Human Resource Management.

Lowe, G. S. (2001). Youth, transitions, and the new world of work. In V. W. Marshall, W. R. Heinz, H. Kruger, \& A. Verma (Eds.), Restructuring work and the life course (pp. 29-44). Toronto: University of Toronto Press.

Maslow, A. H. (1954). Motivation and personality. New York, NY: Harper.

Mathieu, J. E., \& Zajac, D. M. (1990) A review and meta-analysis of the antecedents, correlates, and consequences of organizational commitment. Psychological Bulletin, 108, 171-194. doi: 10.1037/0033-2909.108.2.171

McCann, R. \& Giles, H. (2002). Ageism in the workplace: A communication perspective. In T. D. Nelson (Ed.), Agesim: Stereotyping and prejudice against older persons (pp.163-200). Cambridge, MA: The MIT Press. 
Moen, P., \& Altobelli, J. (2007). Strategic selection as a retirement project: Will Americans develop hybrid arrangements? In J. James \& P. Wink (Eds.), The crown of life: Dynamics of the early postretirement period (pp. 61-82). In K.W. Schaie, (Series Ed.), Annual Review of Gerontology and Geriatrics, 26. New York, NY: Springer Publishing Co.

Mowday, R. T., Steers, R. M., \& Porter, L. W. (1979). The measurement of organizational commitment. Journal of Vocational Behavior, 14, 224-247.

Muller, C., \& Knapp, K. (2003). Occupations in an aging society: Worker abilities and worker interests. Paper presented at the International Research Conference on Social Security, Antwerp, Belgium.

Munnell, A. H., \& Soto, M. (2005). What replacement rates do households actually experience in retirement? (Working Paper No. 10). Chestnut Hill, MA: Center for Retirement Research at Boston College. Retrieved from http://escholarship.bc.edu/cgi/viewcontent.cgi?article=1103\&context=retirement_papers

Munnell, A. H., Sass, S. A., \& Soto, M. (2006). Employer attitudes towards older workers: Survey results. Chestnut Hill, MA: Center for Retirement Research at Boston College. Retrieved from http://crr.bc.edu/images/stories/Briefs/wob_3.pdf

Munnell, A. H., \& Sunden, A. (2004). The challenge of 401(k) plans. New York, NY: Brookings Institute Press.

Newton, T. J., \& Keenan, A. (1983). Is work involvement an attribute of the person or the environment? Journal of Occupational Behavior, 4, 169-178.

Novelli, W. D. (2002). How aging baby boomers will affect American business. Paper presented at the meeting of The Wisemen, New York, NY. 
Nyce, S. A., \& Schieber, S. J. (2001). The decade of the employee: The workforce environment in the coming decade. Benefits Quarterly, 18(1), 60-79.

Odell, A. M. (2007). Engaged employees equal increased earnings. SRI World Group. Retrieved from http://www.socialfunds.com/news/print.cgi?sfArticleId=2399

Peterson, D. A., \& Wendt, P. A. (1995). Training and education of older Americans as workers and volunteers. In S. A. Bass (Ed.), Older and active: How Americans over 55 are contributing to society (pp. 217-236). New Haven, CT: Yale University Press.

Pierce, J. L., \& Dunham, R. B. (1987). Organizational commitment: Pre-employment propensity and initial work experiences. Journal of Management, 1(16), 163-178. doi: $10.1177 / 014920638701300113$

Pierce, J. L., Gardner, D. G., Cummings, L. L., \& Dunham, R. B. (1989). Organization-based self esteem: Construct definition, measurement, and validation. Academy of Management Journal 32(3), 622-648. doi: 10.2307/256437

Pitt-Catsouphes, M., \& Matz-Costa, C. (2008). The multi-generational workforce: Workplace flexibility and engagement. Community, Work \& Family, 11(2), 215-229. doi: $10.1080 / 13668800802021906$

Pitt-Catsouphes, M., \& Matz-Costa, C. (2009). Engaging the 21st century multi-generational workforce: Findings from the age \& generations study (Issue Brief No. 20). Chestnut Hill, MA: Sloan Center on Aging \& Work at Boston College. Retrieved from http://agingandwork.bc.edu/documents/IB20 Engagement 2009-02-10.pdf

Pitt-Catsouphes, M., Matz-Costa, C., \& Besen, E. (2009). Workplace flexibility: Findings from the age and generations study (Issue Brief No. 19). Chestnut Hill, MA: Sloan Center on 
Aging \& Work at Boston College. Retrieved from

http://aginandwork.bc.edu/documents/IB19 WorkFlex 2009-02-04.pdf

Pitt-Catsouphes, M., \& Smyer, M. A. (2006). How old are today's older workers? (Issue Brief No. 04). Chestnut Hill, MA: Boston College Center on Aging \& Work/Workplace Flexibility. Retrieved from http://agingandwork.bc.edu/documents/IB04_HowOldAreWrkrs.pdf

Pitt-Catsouphes, M., Smyer, M. A., Matz-Costa, C., \& Kane, K. (2007). The national study report: Phase II of the national study of business strategy and workforce development (Research Highlight No. 04). Chestnut Hill, MA: The Center on Aging \& Work/Workplace Flexibility. Retrieved from http://agingandwork.bc.edu/documents/RH04_NationalStudy_03-07_004.pdf

Quinn, J. F. (2002). Changing retirement trends and their impact on elderly entitlement programs. In S. H. Altman \& D. Shactman (Eds.), Policies for an aging society. Baltimore, MD: Johns Hopkins University Press.

Rhoades, L., \& Eisenberger, R. (2002). Perceived organizational support: A review of the literature. Journal of Applied Psychology, 87(4), 698-714. doi: 10.1037/00219010.87 .4 .698

Rix, S. E. (2001). Restructuring work in an aging America: What role for public policy? In V. W. Marshall, W. R. Heinz, H. Kruger, \& A. Verma (Eds.), Restructuring work and the life course (pp. 375-396). Toronto: University of Toronto Press.

Robinson, D., Perryman, S., \& Hayday, S. (2004). The drivers of employee engagement (Report No. 408). Institute Employment Studies. Retrieved from http://www.employmentstudies.co.uk/summary/summary.php? $\mathrm{id}=408$ 
Rosen, B., \& Jerdee, T. H. (1976). Influence of age stereotypes on managerial decisions. Journal of Applied Psychology, 61, 428-432. doi: 10.1037/0021-9010.61.4.428

Saks, A. M. (2006). Antecedents and consequences of employee engagement. Journal of Managerial Psychology, 21(7), 600-619. doi: 10.1108/02683940610690169

Schaufeli, W. B., Salanova, M., Gonzales-Roma, V., \& Bakker, A. B. (2002). The measurement of engagement and burnout: A two sample confirmatory factor analytic approach. Journal of Happiness Studies, 3, 71.92. doi: 10.1023/A:1015630930326

Shore, L. M., \& Shore, T. H. (1995). Perceived organizational support and organizational justice. In R. Cropanzano \& K. M. Kacmar (Eds.), Organizational politics, justice, and support: Managing social climate at work (pp. 149-164). Westport, CT: Quorum Press.

Shultz, K. S. (2003). Bridge employment: Work after retirement. In G. A. Adams \& T. A. Beehr (Eds.), Retirement: Reasons, processes, and results (pp.214-241). New York: Springer Publishing Company.

Siebert, A. (2006). Strengthening workforce resiliency in the public sector. The Public Sector, $35,3-7$.

Simpson, P. A., Greller, M. M., \& Stroh, L. K. (2002). Variations in human capital investment activity by age. Journal of Vocational Behavior, 61, 109-138. doi: 10.1006/jvbe.2001.1847

Smith, W. S. (2008). Decoding generational differences: Fact fiction...or should we just get back to work? Deloitte LLP Inc. Retrieved from http://www2.deloitte.com/assets/DcomUnitedStates/Local\%20Assets/Documents/us_Talent_DecodingGenerationalDifferences. pdf 
Smyer, M. A., \& Pitt-Castouphes, M. (2007). The aging workforce: Are we ready? Generations, XXXI(1), 23-30.

Sorensen, A. (2007). The demography of the third age. In J. James \& P. Wink (Eds.), The crown of life: Dynamics of the early postretirement period (pp. 1-17). In K.W. Schaie, (Series Ed.), Annual Review of Gerontology and Geriatrics, 26. New York, NY: Springer Publishing Co.

Stagner, R. (1985). Aging in industry. In J. E. Birren \& K. W. Schaie (Eds.), Handbook of the psychology of aging (pp. 789-817). New York, NY: Van Nostrand Reinhold Company.

Sterns, H. L., \& Doverspike, D. (1989). Aging and the retraining and learning process in organizations. In I. Goldstein \& R. Katzel (Eds.), Training and development in work organizations (pp.229-332). San Francisco, CA: Jossey-Bass.

Sterns, H. L., \& Huyck, M. H. (2001). The role of work in midlife. In M. E. Lachman (Ed.), Handbook of midlife development (pp 447-486). New York, NY: John Wiley.

Sterns, H. L., \& Miklos, S. M. (1995). The aging worker in a changing environment: Organizational and individual issues. Journal of Vocational Behavior, 47, 248-268. doi: 10.1006/jvbe. 1995.0003

Sterns, A. A., Sterns, H. L., \& Hollis, L. A. (1996). The productivity and functional limitations of older adult workers. In W. C. Crown (Ed.), Handbook on employment and the elderly (pp. 276-303). Westport, CT: Greenwood Press.

Swanberg, J., James, J., Werner, M., \& McKechnie, S. (2008). Workplace flexibility for hourly lower-wage employees: A strategic business practice within one national retail firm. The Psychologist Manager Journal, 11(9), 5-29. doi: 10.1080/10887150801963836 
Sweet, S., \& Moen, P. (2006). Advancing a career focus on work and the family: Insights from the life course perspective. In M. Pitt-Catsouphes, E. E. Kossek, \& S. Sweet (Eds.), The work and family handbook: Multi-disciplinary perspectives and approaches (pp. 189208). Mahwah, NJ: Lawrence Erlbaum Associates.

Twenge, J. M., \& Campbell, S. M., (2008). Generational differences in psychological traits and their impact on the workplace. Journal of Managerial Psychology, 23(8), 862-877. doi: $10.1108 / 02683940810904367$

U.S. Census Bureau (2007). Longitudinal employer-household dynamics: 2007/2008 older worker profiles. Retrieved from http://lehd.did.census.gov/led/library/profiles_2007.html.

U.S. Department of Labor (2007). Current population survey household data, annual averages. Retrieved from http://www.bls.gov/cps/cpsaat3.pdf.

Van Deusen, F. R., James, J. B., Gill, N., \& McKechnie, S. P. (2008). Overcoming the implementation gap: How 20 leading companies are making flexibility work. Boston College Center for Work and Family. Retrieved from http://www.bc.edu/centers/cwf/meta-elements/pdf/Flex_ExecutiveSummary_for_web.pdf

Warr, P. (1994). Age and employment. In H. C. Triandis, M. D. Dunnette, \& L. M. Hough (Eds.), Handbook of industrial and organizational psychology $\left(2^{\text {nd }}\right.$ ed., Vol. 4, pp. 485550). New York, NY: Springer Publishing Company.

Warr, P. (2001). Age, work, and mental health. In K. W. Schaie \& C. Schooler (Eds.), Impact of work on older adults (pp.252-303). New York, NY: Springer Publishing Company.

Wayne, S. J., Shore, L. M., \& Liden, R. C., (1997). Perceived organizational support and leadermember exchange: A social exchange perspective. Academy of Management Journal, 40(1), 82-111. doi: 10.2307/257021 
Wefald, A. J., \& Downey, R. G. (2009). The incubator: Job engagement in organizations: Fad, fashion, or folderol? Journal of Organizational Behavior, 30(1), 141-145. doi: $10.1002 /$ job.560

Westerhof, G. J., Barrett, A. E., \& Steverink, N. (2003). Forever young? A comparison of age identities in the United States and Germany. Research on Aging, 25(4), 366-383. doi: $10.1177 / 0164027503025004002$ 
Table 1

Sample Demographics

\begin{tabular}{|c|c|c|c|c|c|}
\hline & $\begin{array}{l}\text { All } \\
\text { Employees }\end{array}$ & $\begin{array}{l}\text { Emerging } \\
\text { Adults } \\
\text { (24 \& } \\
\text { Under) }\end{array}$ & $\begin{array}{l}\text { Settling } \\
\text {-ing } \\
\text { Adults } \\
(25-39)\end{array}$ & $\begin{array}{l}\text { Prime } \\
\text { Working } \\
\text { Years } \\
(40-54)\end{array}$ & $\begin{array}{l}\text { App. } \\
\text { Ret. } \\
(55-65)\end{array}$ \\
\hline $\begin{array}{l}\text { \% of Total } \\
\text { Employees }\end{array}$ & & 33 & 32 & 23 & 9 \\
\hline \multicolumn{6}{|l|}{ Gender } \\
\hline Female & 74 & 32 & 32 & 24 & 9 \\
\hline Male & 26 & 33 & 32 & 22 & 10 \\
\hline \multicolumn{6}{|l|}{ Race } \\
\hline White & 76 & 31 & 29 & 25 & 11 \\
\hline Black & 15 & 35 & 40 & 20 & 4 \\
\hline Other & 9 & 41 & 39 & 16 & 4 \\
\hline
\end{tabular}

Education

Less than High

School

2

45

23

15

15

Ret.

Eligible

High School

Diploma or

31

30

24

29

12

66 \&

equivalent

Some College/2-

Year College

43

44

30

18

Over)

Bachelors Degree

or Above

24

14

46

25

12

3

Marital Status

Married /

Cohabitating

50

14

38

33

12

3

Single/Separated/

Divorced

48

53

27

13

6

1

Widowed

2

Work Hours

Full-Time

63

Part-Time

37

2

5

24

40

27

Exemption Status

Hourly

72

\section{1}

53

23

37

29

14

7

$11 \quad 2$

7

3

39

28

21

9

3 
Employee Engagement

Salaried

28

15

43

30

10

2 
Table 2 .

Factor Loadings and Cronbach's Alpha for Exploratory Factor Analysis with Varimax Rotation of Job Quality Items

\begin{tabular}{|c|c|c|c|c|c|c|}
\hline & \multicolumn{6}{|c|}{ Factor } \\
\hline & 1 & 2 & 3 & 4 & 5 & 6 \\
\hline My supervisor is supportive when I have a work problem & .78 & .28 & .11 & .13 & .060 & -.04 \\
\hline $\begin{array}{l}\text { My supervisor really cares about the effects that work } \\
\text { demands have on my personal and family life }\end{array}$ & .77 & .33 & .11 & .12 & .11 & -.03 \\
\hline I feel valued as an employee of CitiSales. & .76 & .23 & .23 & .15 & .12 & -.07 \\
\hline I am recognized when I do good work. & .71 & .17 & .35 & .18 & .07 & -.06 \\
\hline $\begin{array}{l}\text { I am encouraged to come up with new and better ways of } \\
\text { doing things. }\end{array}$ & .65 & .15 & .41 & .13 & .16 & -.05 \\
\hline $\begin{array}{l}\text { I am allowed to make the decisions necessary to do my } \\
\text { job well. }\end{array}$ & .57 & .20 & .37 & .24 & .12 & -.05 \\
\hline $\begin{array}{l}\text { I receive the necessary level of training to perform my job } \\
\text { effectively. }\end{array}$ & .42 & .24 & .29 & .40 & .08 & -.07 \\
\hline $\begin{array}{l}\text { How often are your preferences about the days and times } \\
\text { of when you work taken into consideration by the person } \\
\text { who writes your schedule }\end{array}$ & .21 & .76 & .07 & .01 & .06 & -.06 \\
\hline $\begin{array}{l}\text { Overall, in the past month how satisfied have you been } \\
\text { with the weekly schedule you've been assigned }\end{array}$ & .20 & .74 & .17 & .07 & .12 & -.03 \\
\hline $\begin{array}{l}\text { How much input do you have into the number of hours } \\
\text { you work each week }\end{array}$ & .07 & .68 & .16 & .01 & .02 & .03 \\
\hline $\begin{array}{l}\text { I have the ability to change my schedule when I have } \\
\text { family or personal business to take care of }\end{array}$ & .27 & .61 & .02 & .35 & .04 & -.06 \\
\hline $\begin{array}{l}\text { How often are the people you work with willing to swap } \\
\text { hours with you or cover for you when you need to take } \\
\text { time off for a personal or family matter }\end{array}$ & .16 & .60 & .06 & .07 & .19 & -.09 \\
\hline $\begin{array}{l}\text { When an unexpected personal or family matter arises, I } \\
\text { have the ability to modify my schedule }\end{array}$ & .30 & .56 & .03 & .33 & .01 & -.09 \\
\hline $\begin{array}{l}\text { Think about when you generally learn about your work } \\
\text { schedule; is it more than enough, enough, or not enough } \\
\text { time to plan personal, family, or other responsibilities }\end{array}$ & .11 & .54 & .19 & .15 & .00 & -.04 \\
\hline $\begin{array}{l}\text { I have sufficient access to career development } \\
\text { opportunities }\end{array}$ & .25 & .18 & .81 & .12 & .16 & -.06 \\
\hline My chances of being promoted at CitiSales are good & .25 & .14 & .79 & .07 & .11 & -.08 \\
\hline $\begin{array}{l}\text { I have a clear understanding of the career paths available } \\
\text { to me within CitiSales }\end{array}$ & .24 & .18 & .77 & .18 & .08 & -.05 \\
\hline I understand how my performance is evaluated. & .44 & .17 & .56 & .26 & .06 & -.05 \\
\hline
\end{tabular}


I have the general tools and resources I need to do my job well

$\begin{array}{lllllllll}\text { I have a clear understanding of what is expected of me } & & .13 & .11 & .12 & .77 & .04 & -.02\end{array}$

I am generally able to get my work done without facing too much red tape or bureaucracy

$\begin{array}{llllll}.27 & .11 & .15 & .61 & .613 & -.06\end{array}$

I have a positive impact on other people's lives through my job

My job is interesting and challenging

$\begin{array}{llllll}.17 & .11 & .02 & -.11 & .72 & -.09\end{array}$

My job makes full use of my skills and abilities

$\begin{array}{llllll}.12 & .11 & .22 & .41 & .68 & .02\end{array}$

In decisions about promotion, CitiSales gives younger

people preference over older people.

$\begin{array}{llllll}.07 & .12 & .33 & .38 & .63 & .04\end{array}$

$\begin{array}{llllll}-.01 & -.02 & -.07 & -.04 & .03 & .85\end{array}$

At CitiSales, employees who ask for time off for family reasons are less likely to get ahead in their jobs or careers.

Note. Factor 1: Supervisor Support \& Recognition $(\alpha=0.89)$; Factor 2: Schedule Satisfaction $(\alpha=0.81)$;

Factor 3: Career Development \& Promotion $(\alpha=0.86)$; Factor 4: Job Clarity $(\alpha=0.72)$; Factor 5: Intrinsic Job Satisfaction $(\alpha=0.64)$; Factor 6: Fairness $(\alpha=0.58)$. 
Table 3

Employee Engagement by Age Group: Bonferroni Post Hoc Results

\begin{tabular}{|c|c|c|c|c|}
\hline $\begin{array}{l}\text { Employer Engagement by Age } \\
\text { Categories }\end{array}$ & $\begin{array}{l}\text { Age } \\
\text { Categories }\end{array}$ & $\begin{array}{c}\text { Mean } \\
\text { Difference }\end{array}$ & $\begin{array}{l}\text { Std. } \\
\text { Error }\end{array}$ & $t$ \\
\hline Emerging Adults & $25-39$ & -0.94 & .21 & $4.41 *$ \\
\hline 24 an younger & $40-54$ & -2.04 & .23 & $8.81 *$ \\
\hline Mean $=31.17$ & $55-65$ & -2.57 & .31 & $8.17 *$ \\
\hline s.d. $=6.515$ & 66 and older & -3.11 & .55 & $5.63^{*}$ \\
\hline $\begin{array}{l}\text { Settling-In Adults } \\
25-39\end{array}$ & $\begin{array}{l}24 \text { and } \\
\text { younger }\end{array}$ & 0.94 & .21 & $4.41 *$ \\
\hline Mean $=32.11$ & $40-54$ & -1.10 & .23 & $4.74 *$ \\
\hline \multirow[t]{2}{*}{ s.d. $=6.303$} & $55-65$ & -1.62 & .31 & $5.17 *$ \\
\hline & 66 and older & -2.17 & .55 & $3.92 *$ \\
\hline $\begin{array}{l}\text { Prime-Working Years } \\
40-54\end{array}$ & $\begin{array}{l}24 \text { and } \\
\text { younger }\end{array}$ & 2.04 & .23 & $8.81 *$ \\
\hline Mean $=33.21$ & $25-39$ & 1.10 & .23 & $4.74 *$ \\
\hline \multirow[t]{2}{*}{ s.d. $=5.643$} & $55-65$ & -0.52 & .33 & 1.60 \\
\hline & 66 and older & -1.07 & .56 & 1.91 \\
\hline $\begin{array}{l}\text { Approaching Retirement } \\
55-65\end{array}$ & $\begin{array}{l}24 \text { and } \\
\text { younger }\end{array}$ & 2.57 & .31 & $8.17^{*}$ \\
\hline Mean $=33.74$ & $25-39$ & 1.62 & .31 & $5.17 *$ \\
\hline \multirow[t]{2}{*}{ s.d. $=5.317$} & $40-54$ & 0.52 & .33 & 1.60 \\
\hline & 66 and older & -0.54 & .60 & 0.91 \\
\hline $\begin{array}{l}\text { Retirement Eligible } \\
66 \text { and older }\end{array}$ & $\begin{array}{l}24 \text { and } \\
\text { younger }\end{array}$ & 3.11 & .55 & $5.63 *$ \\
\hline Mean $=34.28$ & $25-39$ & 2.17 & .55 & $3.92 *$ \\
\hline \multirow[t]{2}{*}{ s.d. $=4.606$} & $40-54$ & 1.07 & .560 & 1.91 \\
\hline & $55-65$ & 0.54 & .560 & 0.91 \\
\hline
\end{tabular}

Note: ${ }^{*} p<.001$. 
Table 4

Correlation Coefficients

\begin{tabular}{|c|c|c|c|c|c|}
\hline & 1 & 2 & 3 & 4 & 5 \\
\hline $\begin{array}{l}\text { 1. Employee } \\
\text { Engagement }\end{array}$ & 1.000 & & & & \\
\hline $\begin{array}{l}\text { 2. Supervisor Support \& } \\
\text { Recognition }\end{array}$ & $.350^{*}$ & 1.000 & & & \\
\hline 3. Schedule Satisfaction & $.163^{*}$ & .000 & 1.000 & & \\
\hline $\begin{array}{l}\text { 4. Career Development } \\
\text { \& Promotion }\end{array}$ & $.365^{*}$ & .000 & .000 & 1.000 & \\
\hline 5. Job Clarity & $.232^{*}$ & .000 & .000 & .000 & 1.000 \\
\hline
\end{tabular}


Table 5

All Age Groups Employee Engagement and Job Quality Factors Regression Analyses

\begin{tabular}{|c|c|c|c|c|c|c|c|c|c|c|}
\hline & \multicolumn{2}{|c|}{$\begin{array}{l}\text { Emerging } \\
\text { Adults } \\
\text { (24 and } \\
\text { Under) }\end{array}$} & \multicolumn{2}{|c|}{$\begin{array}{l}\text { Settling-in } \\
\text { Adults } \\
(25-39)\end{array}$} & \multicolumn{2}{|c|}{$\begin{array}{l}\text { Prime- } \\
\text { Working } \\
\text { Years } \\
(40-54)\end{array}$} & \multicolumn{2}{|c|}{$\begin{array}{c}\text { Approach. } \\
\text { Retirement } \\
(55-65)\end{array}$} & \multicolumn{2}{|c|}{$\begin{array}{l}\text { Retirement- } \\
\text { Eligible } \\
\text { (66 and over) }\end{array}$} \\
\hline & $\begin{array}{c}\text { B } \\
(\text { S. E.) }\end{array}$ & $\beta$ & $\begin{array}{c}\text { B } \\
(\text { S. E. })\end{array}$ & $\beta$ & $\begin{array}{c}\text { B } \\
(\text { S. E.) }\end{array}$ & $\beta$ & $\begin{array}{c}\text { B } \\
(\text { S. E.) }\end{array}$ & $\beta$ & $\begin{array}{c}\text { B } \\
\text { (S. E.) }\end{array}$ & $\mathrm{B}$ \\
\hline Female & $1.02^{* *}$ & .07 & 0.77 & .05 & $1.32^{*}$ & .08 & -0.20 & - & 3.39 & .33 \\
\hline Dummy & $(.39)$ & & $(.48)$ & & $(.58)$ & & $(.86)$ & .01 & $(1.74)$ & \\
\hline $\begin{array}{l}2 \text {-year or } \\
\text { some college } \\
\text { Dummy }\end{array}$ & $\begin{array}{c}-1.05^{* *} \\
(.38)\end{array}$ & -.08 & $\begin{array}{l}-0.66 \\
(.45)\end{array}$ & -.05 & $\begin{array}{l}0.51 \\
(.42)\end{array}$ & .04 & $\begin{array}{l}-0.33 \\
(.60)\end{array}$ & .03 & $\begin{array}{c}0.79 \\
(1.37)\end{array}$ & .07 \\
\hline $\begin{array}{l}\text { Bachelors } \\
\text { degree or } \\
\text { above } \\
\text { Dummy }\end{array}$ & $\begin{array}{c}-2.10^{* *} \\
(.68)\end{array}$ & -.09 & $\begin{array}{c}-2.65^{* *} \\
(.60)\end{array}$ & -.17 & $\begin{array}{l}0.60 \\
(.622)\end{array}$ & .04 & $\begin{array}{c}0.27 \\
(.970)\end{array}$ & .02 & $\begin{array}{c}-0.00 \\
(4.395 \\
)\end{array}$ & .00 \\
\hline $\begin{array}{l}\text { Single } \\
\text { Dummy }\end{array}$ & $\begin{array}{l}-1.46 \\
(1.34)\end{array}$ & -.09 & $\begin{array}{l}-0.58 \\
(.70)\end{array}$ & -.04 & $\begin{array}{l}-1.20 \\
(.70)\end{array}$ & .06 & $\begin{array}{l}-0.10 \\
(1.07)\end{array}$ & .00 & $\begin{array}{c}1.46 \\
(2.42)\end{array}$ & .08 \\
\hline $\begin{array}{l}\text { Married } \\
\text { Dummy }\end{array}$ & $\begin{array}{l}-0.69 \\
(1.36)\end{array}$ & -.04 & $\begin{array}{l}-0.07 \\
(.66)\end{array}$ & -.01 & $\begin{array}{l}-0.27 \\
(.46)\end{array}$ & $\begin{array}{c}- \\
.02\end{array}$ & $\begin{array}{l}-0.53 \\
(.58)\end{array}$ & $\begin{array}{c}- \\
.05\end{array}$ & $\begin{array}{l}-1.30 \\
(1.22)\end{array}$ & -.14 \\
\hline $\begin{array}{l}\text { Part-Time } \\
\text { Dummy }\end{array}$ & $\begin{array}{l}0.54 \\
(.36)\end{array}$ & .04 & $\begin{array}{l}-0.06 \\
(.42)\end{array}$ & -.00 & $\begin{array}{l}-0.42 \\
(.45)\end{array}$ & $\begin{array}{c}- \\
.03\end{array}$ & $\begin{array}{c}-1.82^{* *} \\
(.59)\end{array}$ & $\begin{array}{l}- \\
.16\end{array}$ & $\begin{array}{l}-1.36 \\
(1.21)\end{array}$ & -.14 \\
\hline $\begin{array}{l}\text { Hourly } \\
\text { Dummy }\end{array}$ & $\begin{array}{l}-1.26^{*} \\
(.62)\end{array}$ & -.06 & $\begin{array}{c}-2.16^{* *} \\
(.57)\end{array}$ & -.13 & $\begin{array}{l}-0.80 \\
(.62)\end{array}$ & .05 & $\begin{array}{c}0.90 \\
(1.12)\end{array}$ & .05 & $\begin{array}{l}-4.07 \\
(4.32)\end{array}$ & -.29 \\
\hline $\begin{array}{l}\text { Supervisor } \\
\text { Support \& } \\
\text { Recognition }\end{array}$ & $\begin{array}{l}2.44^{* *} \\
(.18)\end{array}$ & .37 & $\begin{array}{l}2.21^{* *} \\
(.18)\end{array}$ & .35 & $\begin{array}{l}2.11^{* *} \\
(.19)\end{array}$ & .38 & $\begin{array}{l}2.30^{* *} \\
(.28)\end{array}$ & .41 & $\begin{array}{l}3.67^{* *} \\
(.87)\end{array}$ & .50 \\
\hline $\begin{array}{l}\text { Schedule } \\
\text { Satisfaction }\end{array}$ & $\begin{array}{l}1.16^{* *} \\
(.18)\end{array}$ & .17 & $\begin{array}{l}1.04^{* *} \\
(.19)\end{array}$ & .16 & $\begin{array}{l}0.84^{* *} \\
(.18)\end{array}$ & .15 & $\begin{array}{l}0.73^{*} \\
(.28)\end{array}$ & .13 & $\begin{array}{l}1.85^{*} \\
(.72)\end{array}$ & .33 \\
\hline $\begin{array}{l}\text { Career } \\
\text { Development } \\
\text { \& Promotion }\end{array}$ & $\begin{array}{l}2.88^{* *} \\
(.18)\end{array}$ & .44 & $\begin{array}{l}2.56^{* *} \\
(.18)\end{array}$ & .40 & $\begin{array}{l}2.20^{* *} \\
(.19)\end{array}$ & .37 & $\begin{array}{l}1.54^{* *} \\
(.28)\end{array}$ & .28 & $\begin{array}{l}.59 \\
(.72)\end{array}$ & .10 \\
\hline Job Clarity & $\begin{array}{l}1.64^{* *} \\
(.19)\end{array}$ & .23 & $\begin{array}{l}1.90^{* *} \\
(.20)\end{array}$ & .28 & $\begin{array}{l}1.58^{* *} \\
(.18)\end{array}$ & .29 & $\begin{array}{l}2.10^{* *} \\
(.28)\end{array}$ & .38 & $\begin{array}{l}1.99^{* *} \\
(.68)\end{array}$ & .36 \\
\hline$R^{2}$ & .40 & & .39 & & .40 & & .48 & & .49 & \\
\hline $\begin{array}{l}\text { Adj. } R^{2} \\
F\end{array}$ & $51.73^{* *}$ & & $\begin{array}{c}.38 \\
44.19^{*}\end{array}$ & & $\begin{array}{c}.38 \\
34.51^{* *}\end{array}$ & & $\begin{array}{c}.45 \\
18.18^{*}\end{array}$ & & $\begin{array}{c}.35 \\
3.57^{* *}\end{array}$ & \\
\hline Cohen's $f^{2}$ & .65 & & .63 & & .65 & & .91 & & .95 & \\
\hline
\end{tabular}

